\title{
Evaluation of the Variation of the Contents of Anti-Nutrients and Nutrients in the Seeds of Legumes
}

\author{
Jerzy Księżak, Jolanta Bojarszczuk \\ Institute of Soil Science and Plant Cultivation - State Research Institute in Pulawy \\ Department of Forage Crop Production, Czartoryskich St. 8, 24-100 Pulawy, Poland
}

\begin{abstract}
It is assumed that the content of anti-nutrients in legumes seeds and find out the dependency among their content and the amount of important nutrients. The influence of the agri-environmental conditions on concentration of anti-nutrients was evaluated on the basis of the analysis of the material collected from the experiments carried out in the years 2010-2011, located in different regions of Poland. The analyses were performed in the Main Chemical Laboratory of IUNG-PIB Pulawy and in Laboratory of Research Centre for Cultivar Testing (COBORU) in Stupia Wielka, near Poznan. The obtained results indicate that the region of cultivation did not have a significant impact on the concentration of these substances in the seeds of faba bean. Seeds of fodder pea of Muza and Marych cultivars contain significantly less tannins than Roch and Wiato cultivars. In the case of faba bean, however, fewer of these compounds were found at white-flowering cultivars. The average content of total alkaloids in lupine was definitely greater in blue lupine than in yellow lupine. The location of cultivation of yellow lupine did not have an influence on the level of total alkaloids and gramine. Blue lupine collected much less alkaloids in the location of Central Poland and significantly more in the North and West of Poland.
\end{abstract}

Keywords: anti-nutrient substances, legumes, location of cultivation, nutrients, seeds

\section{Introduction}

Species belonging to the legumes are important group of major economic importance in the global scale [1]. They are grown for seeds used for the purpose of industry (oil production), consumption and fodder, and also as a raw material for the production of nutritive fodder, green forage, green manure and for reclamation of fallow ground. They are characterized, as one of the few groups of crops, by a positive balance of organic matter in the soil. They are also an excellent forecrop for cereal, industrial and root crops. Climatic conditions in Poland allow to the cultivation of these plants in the whole country [2]. They can be cultivated both in holdings with organic farming and sustainable production system. Because of the economic importance and natural values, they play an important role in crop production. In the last several years, cropping area under cultivation has undergone large changes. The largest area of 385 thousand hectares was taken by legumes in 1989. Their share in the cropping pattern amounted to $3.6 \%$. It was connected to the marketing plan based on the country's self-sufficiency in raw materials for the production of nutritive fodder, in which the legume seeds, were the main source of protein. International situation, which creates problems with obtaining high protein soy pellets is also significant. The interest of farmers in cultivating legumes has been varied over time and depended largely on the demand for seeds and the profitability of their cultivation.

The main factor, which determines the size of cultivation area of this group of plants is the availability and soy pellets price. The introduction of free market economy in the late 1980s and 1990s resulted in many changes in agriculture that affected the evolution of the economic factors, agrarian structure and the associated structures under cultivation. The cultivation area of legumes decreased rapidly in this period. However, in the last 2-3 years, there has been an increase of cultivation area (in the year 2011 over 150000 hectares and the share in the cropping pattern by more than $1,2 \%$ ) (data not published).

An important feature of seeds legume is the content of the anti-nutritional substances, which negatively affect the use of nutrients and compounds negatively affected the health and growth of animals called: growth depressing factors $[3,4]$. Anti-nutritive and anti-nutrional components have or may have a harmful effect on the nutritive, technological and sensory value of seeds or the products obtained from them. The researches of experiments on these compounds are meant to clarify their role and deepen knowledge about their action, which does not change the fact that their presence limits the full use of high-value protein in the legumes seeds. They cause a decrease in the consumption of feed, as well as a reduction in the use of the nutrients, and often cause a damage to the cells of intestinal epithelium and excessive growth of internal organs $[\mathbf{5 , 6 , 7 ]}$. Negative impact on digestion and utilization of nutrients - proteins, carbohydrates and mineral compounds was shown by inhibitors of enzymes: trypsin, chymotrypsin, amylase, phenolic compounds, and especially condensed tannins, most lectin and oligosaccharides [-8]. 
In order to reduce the quantities of anti-nutrients in legume seeds, various thermal and hydrothermal processes are used, such as dry heating, steam heating or cooking, autoclaving or mechanical heating (e.g. removing a seed coat). There have been attempts to use some of the industrial methods which combine thermal and mechanical actions such as microionization, extrusion, flaking and pelleting $[9,10,11,12,13,14,15,16$, 17, 18]. In addition, [19] indicate that in many cases, the use one method only, may be not effective enough, and it is then necessary to combine two or more methods. At the same time, heating feed for too long and in too high temperature causes the decrease of availability of amino acids and the possibility of binding tannins in complexes with protein. Moreover, carrying out these experiments requires additional financial input, which raises the cost of feed production. Technological processes aimed at improving the nutritive value of legume seeds of have not yet come out of the phase of the experiments. The standards of technological conditions for this treatment have not been developed. Inappropriate conditions cause the decrease in the availability of amino acids, as well as in the nutritional value of the proteins. Mechanical removal of the seed coat of faba bean and lupine causes an increase of the energy value of these seeds and may be economically justifiable only in poultry feeding. There is only little information about the impact of the agri-environmental factors on accumulation of ant-nutrients in the legumes seeds. It was shown with that the environment can affect the activity of trypsin inhibitor [20]. The relationship between content of these compounds in seeds legume and quantity of the important nutrients has also been little recognized.

The aim of the research was to determine the content of anti-nutrients in seeds legume and find out the dependency among their content and the amount of nutrients.

\section{Materials And Methods}

The influence of the agri-environmental conditions on concentration of anti-nutrients was evaluated on the basis of the analysis of the material collected from the experiments carried out in the years 2010-2011, located in different location of the country.

Simples of all species seeds were marked for the contents of major nutrients (crude fibre - by weight method, crude fat - by Soxhlet's weight method, N - by flow spectrophotometry, crude ash - by weight method at $580^{\circ} \mathrm{C}$, sugars and starches).

Field and laboratory experiments were performed on 9 different faba bean cultivars, 13 fodder pea, 8 yellow lupine, 14 blue lupine, derived from harvests.

The determination of alkaloid contamination in yellow lupine (gramine) and blue lupine (total alkaloids) has been made by the Spanish method of capillary gas-liquid chromatography (GLC). Alkaloid extracts were separated by gas chromatography on fused-silica capillary columns (15 m long, 0,25 mm diameter; SE 30 or DB 1; J\&W Scientific; obtained from ICT, Frankfurt, FRG). Conditions for GLC: injector: $250^{\circ} \mathrm{C}$; detector: $320^{\circ} \mathrm{C}$; oven: $150-300^{\circ} \mathrm{C}, 15^{\circ} \mathrm{C} \mathrm{min}^{-1}$, at $300^{\circ} \mathrm{C}$ isothermal for $10 \mathrm{~min}$; carrier gas: helium $(1$ bar); make-up gas: $20 \mathrm{ml} \mathrm{min}^{-1}$ helium; split injection: 1:25. Sparteine was used as an external standard [21].

The seeds of faba bean and fodder pea were marked for the content of tannins by method of [22]. Simples were determined by the vanillin method with using sulphuric acid.

The analyses were performed in the Main Chemical Laboratory and in the Department of Biochemistry and Crop Quality of Institute of Soil Science and Plant Cultivation-State Research Institute in Puławy and in Laboratory of Research Centre for Cultivar Testing (COBORU) in Słupia Wielka, near Poznań.

\section{Results And Discussion}

Tannins are important compounds in the seeds of cultivars of faba bean and fodder pea. They cause the reduction of the digestibility of the proteins and carbohydrates, reduce the availability of methionine and iron and deteriorate the feed taste. Seeds of fodder pea of Muza and Marych cultivars contain significantly fewer of these compounds. More of them were found at Roch and Wiato cultivars (Table 1). The seeds of whiteflowering cultivars of faba bean including Leo, Kasztelan, Albus, Amulet, and Olga, were characterized by a smaller amount of these compounds, and more of them were found at Boskovic, Sonet, Granit, and Optimal (Table 1). According to[3], the seeds of Ballet cultivar of pea contained significantly more of tannins than Renata and Solara cultivars. [23] recorded large variation in the total oligosaccharides in seeds of cultivars of pea. According to [20], tannins are most often present in the seeds of cultivars of colorful flowers which may be used in the production of feed, although they are often characterized by a lower digestibility of proteins compared to other cultivars of pea. [24]shows that low content of tannins is related to white colour of flowers, which is controlled by at least two recessive genes.[25] state that an alternative method to the chemical method used to reduce of content of tannins is breeding cultivars with a low concentration of tannins, which is controlled by the same gene as the white colour of the flowers. However, according to [20], the seeds of cultivars without tannins have a wide application both in human and animal feeding.

In the Southern part of the Poland, the seeds of pea cultivars accumulated significantly less of these compounds, and substantially more in the North-East and the Midwest. Correlation analysis showed that crude 
fibre, starch, tannins, and the soil $\mathrm{pH}$ of adversely affect the protein content in seeds of fodder pea, but it is positively correlated with quantity of sugars and soil complex (Table 5). The increase the crude fibre content in the seeds is significantly affected by the soil complex, but it is reduced by the concentration of sugars. Accumulation of tannins is induced by the content of sugars and soil $\mathrm{pH}$. The amount of sugars and starch are adversely affected by the soil $\mathrm{pH}$ and the total precipitation during the growing season. The location of cultivation did not have a significant influence on the concentration of these substances in faba bean seeds (Table 4). Tannins and sugars found in seeds of faba bean cause a temporary limit in the content of protein, crude fibre and crude ash and increase in the amount of crude fat. Protein content in seeds was increased by the content of crude fibre but reduced by crude fat. The content of the evaluated nutrients in the faba bean seeds was insignificantly impacted by the total precipitation during the growing period and soil $\mathrm{pH}$.

Alkaloids occurring in yellow and blue lupine can act as stimulants, anesthetics, and even poisons. They affect central nervous system causing its paralysis, and furthermore, they may cause severe stomach pains and vomiting. If consumed in small quantities, they decrease the absorption of feed and growth of animals. Seeds of cultivars of yellow lupine contain a similar amount of alkaloids. More of them were found at cultivars of blue lupine such as Mirela and Karo (Table 2). Other cultivars contained a significantly smaller amount of them. A greater quantity of alkaloids in the seeds of Mirela and Karo cultivars was recorded in previously researches by [26]. In addition, the average total alkaloids in lupine were definitely higher in the seeds of blue lupine than at yellow lupine. The indole alkaloid gramine is toxic to animals and may play a defensive role in plants, especially if it occurs in significant quantities. All evaluated cultivars of yellow lupine contain little of gramine, but its slightly higher amount was found at Parys cultivar (Table 3). [27] consider that breeding cultivars of lupine with low content of alkaloids (called: sweet) is one of the greatest achievements of breeders. New lupine cultivars usually contain less than $200 \mathrm{mg} \mathrm{kg}^{-1}$ of alkaloids [27]. The location, where lupine was grown did not have an effect on the level of total alkaloids and gramine in the seeds. The data obtained from the correlation analysis suggests that the contents of crude fibre and crude fat adversely affect the protein content of lupine, and that the soil complex is positively correlated with protein content. Increase the crude fibre content in seeds is significantly affected by the content of crude fat and forecrop after, which lupine is cultivated. The amount of crude fat was reduced by the total of precipitation during the growing season. Accumulation of alkaloids was induced by soil quality and the sugars - by forecrop. According to [28], there is a correlation among the level of alkaloids in lupine and the level of precipitation in the period of flowering of plants. According to this author, the drought in this period significantly increases the level of alkaloids in lupine. A similar tendency of changes in the content of alkaloids in white lupine (Hetman cultivar) and blue lupine (Saturn cultivar) was observed by [29]. Much less of these compounds were collected from the seeds of blue lupine in the region of Central of Poland and significantly more in the North and West of Poland. The protein content in blue lupine, similarly as in yellow lupine, was negatively correlated with crude fat content, crude fibre content and the soil $\mathrm{pH}$. An increase in the crude fibre content in seeds was positively affected by quantity of sugars, and adversely affected by agro-environmental factors. Crude fat content was positively correlated with soil quality and negatively correlated with the content of sugars, forecrop and total of precipitation. The quantity of alkaloids and starch was not correlated with any of the evaluated nutrients and habitat conditions.

The seeds of cultivar of multiuse pea contain traces of tannins. The accumulation of protein was induced by the quality of soil and total precipitation, but negatively impacted by sugars and soil $\mathrm{pH}$. The accumulation of crude fibre was enhanced by greater total of precipitation, but limited by soil $\mathrm{pH}$. Increase in the content of sugars was caused by the soil $\mathrm{pH}$ and forecrop, but limited by soil quality, total precipitation and starch content.

\section{Conclusions}

Seeds of fodder pea of Muza and Marych cultivars contain significantly less tannins than Roch and Wiato cultivars. In the case of faba bean, however, fewer of these compounds were found at white-flowering cultivars such as Leo, Kasztelan, Albus, Amulet and Olga. Multipurpose cultivars of peas contain traces of tannin. In the southern part of the country, seeds of pea accumulated much less of these compounds, while significantly more in the North-Eastern of Poland and the Midwest. The region of cultivation did not have a significant impact on the concentration of these substances in the seeds of faba bean.

The average content of total alkaloids in lupine was definitely greater in blue lupine than in yellow lupine. Seeds of yellow lupine cultivars contained a similar amount of alkaloids, while the cultivars of blue lupine such as Mirela and Karo were characterized by their higher amount than other cultivars.

All the evaluated cultivars of yellow lupine contained little of gramine and only slightly more of it was found at Parys cultivar. The region of cultivation of yellow lupine did not have an influence on the level of total alkaloids in the seeds and gramine. Blue lupine collected much less alkaloids in Central of Poland and significantly more in the North and West of Poland. 


\section{Acknowledgements.}

Article performed under Ini Tech project "The possibility of increasing of protein production from seeds of national leguminous varieties cultivated in differentiated climatic conditions", financed by The National Centre for Research and Development (no 64692).

\section{References}

[1] A. Mikić, B. Ćupina, S. Katić, D. Karagić, Importance of annual forage legumes in supplying plant proteins, A Periodical of Scientific Research on Field and Vegetable Crops, 42, I, 2006, 91-103.

[2] J. Księżak, M. Staniak, J. Bojarszczuk, The regional differentiation of legumes cropping area in Poland within 2001-2007, Polish Journal of Agronomy, 1, 2009, 25-31.

[3] R. Alonso, E. Orúe, F. Marzo, Effects of extrusion and conventional processing methods on protein and antinutritional factor contents in pea seeds, Food Chemistry, 63(4), 1998, 505-512.

[4] F. Gatel, F. Grosjen, Comosition and nutritive value of peas for pigs: a review of European results, Livestock Production Science, 26, 1990, 155-175.

[5] H. Leontowicz, M. Leontowicz, H. Kostyra, M.A. Gralak, G.W. Kulasek, The influence of extrusion or boiling on trypsin inhibitor and lectin activityin leguminous seeds and protein digestibility in rats, Polish Journal of Food and Nutrition Science, 4, 1999, 7787.

[6] R. Mosenthin, D. Jezierny, Nutritional significance of secondary plant metabolites in pigs and poultry, 19 International Science Symposium on Nutrition of Domestic Animals, 2010, 227-236.

[7] R Matić, S. Nagel, S. Robertson, I. Young, V. Mihailović, A. Mikić, G. Kirby, Vetch (Vicia ssp) expansion and use in Australia, Biotechnology in Animal Husbandry, 21, 5-6, 2, 2005, 203-207.

[8] A.W. Piastowska, M.A. Gralak, Effect of legume seeds contained in the diet on bone structure, Postepy Nauk Rolniczych, 6, 2004, $17-27$.

[9] K.E. Akande, E.F. Fabiyi, Effect of Processing Methods on Some Antinutritional Factors in Legume Seeds for Poultry Feeding, International Journal of Poultry Science, 9, 2010, 996-1001.

[10] L. Conan, B. Carré, Effect of autoclaving on metabolizable energy value of smooth pea seed (Pisum sativum) in growing chicks, Animal Feed Science and Technology, 26, 1989, 337-345

[11] A.F.B. Van der Poel, Effect of processing on antinutritional factors and protein nutritional value of dry beans (Phaseolus vulgaris L.). A review, Animal Feed Science and Technology, 29, 1990, 179-208.

[12] N.G. Almeida Calderón, A.M. de la Barca, E.V Mauro, Effect of different heat treatments on the nutritional activity of Phaseolus vulgaris (variety Ojo de Cabra) lectin, Journal of A gricultural and Food Chemistry, 39, 1991, 1627-1630.

[13] Y.A. Kim, W.E. Barbeau, Changes in the nutritive value of soy protein concentrate during autoclaving, Plant Foods for Human Nutrition, 41, 1991, 179-192.

[14] E. Gujska, K. Khan, Feed moisture effects on functional properties, trypsin inhibitor and hemagglutinating activities of extruded bean high starch fraction,. Journal of Food Science, 56, 1991, 443-447.

[15] S. Bishnoi, N. Khetarpaul, Effect of domestic processing and cooking methods on in-vitro starch digestibility of different pea cultivars (Pisum sativum), Food Chemistry, 47, 1993, 177-182.

[16] J. Fŕias, C. Diaz-Pollan, C.L. Hedley, C. Vidal-valverde, Evolution of trypsin inhibitor activity during germination of lentils, Journal of Agricultural and Food Chemistry, 43, 1995, 2231-2234.

[17] H.M. Bau, C. Villaume, J-P. Nicolas, L. Méjean, Effect of germination on chemical composition, biochemical constituents and antinutritional factors of soya bean (Glycine max) seeds, Journal of the Science of Food and Agriculture, 73, 1997, 1-9.

[18] N. Wang, M.J. Lewis, J.G. Bernnan, A. Westby, Effect of processing methods on nutrients and anti-nutritional factors in cowpea, Food Chemistry, 58, 1997, 59-68.

[19] A. Mikić, V. Perić, V. Đorđević, M. Srebrić, V. Mihailović, Anti-nutritional factors in some grain legumes, Biotechnology in Animal Husbandry, 25(5-6), 2009, 1181-1188.

[20] M. Wink, Inhibition of seed germination by quinolizidine alkaloids, Aspect of allelopathy in Lupinus albus L., Planta 158, 1983, 365-368.

[21] S. Kuhla, C. Emmeier, Untersuchungen zum Taningehalt in Ackerbohnen, Arch. Tierenaehr. 31, 1981, 573-588

[22] A. Racevičiūtè-Stupelienè, V. Šašyt è, R. Gružauskas, Antinutritioanl feed factors in varieties of oilseed rape (Brassica napus L.) and peas (Pisum sativum L.) grown in Lithuania, Acta Biologica University Daugavpils. 6(1-2), 2006, 141-149.

[23] G. Duc, Faba bean (Vicia faba L.). Field Crops Research, 53, 1997, 99-109.

[24] D.A. Bond, D.B. Smith, in J. Huisman, A.F.B. van der Poel and I.E. Liener (Ed.), Possibilities for the reduction of antinutritional factors in grain legumes by breeding. In recent Advances of research in antinutritional Factors in Legume Seeds, Wageningen Pudoc., 1989, 285-296.

[25] J. Księżak, M. Staniak, J. Bojarszczuk, Differentiation of anti-nutritional substances in legume seeds, Acta Biochimica Polonica, 58 (suppl. 3), 2011, 40-42.

[26] W.A Cowling, B.J. Buirchell, M.E. Tapia, Lupin. Lupinus L. (Institute of Plant Genetics and Crop Plant Research, Gatersleben, Germany-International Plant Genetic Resources Institute, Rome, Italy), 1998, 105.

[27] J.L. Christainsen, S. Buskov, J. Jornsgard, Effect of drought stress od seeds alkaloid content in Lupinus angustifolius. Proc.8th International Lupin Conf., California, 24, 1996.

[28] J. Wasilewko, L. Buraczewska, Chemical composition including content of amino acids, minerals and alkaloids in seeds of three lupin species cultivated in Poland, Journal of Animal and Feed Science, 8, 1999, 1-12. 
Evaluation of the Variation of the Contents of Anti-Nutrients and Nutrients in the Seeds of Legumes

Table 1. The content of tannins in seeds of faba bean cultivars in the 2010-2011 years (\% d.m.)

\begin{tabular}{|c|c|c|c|c|c|}
\hline Cultivar & 2010 & $\begin{array}{c}\text { Homogeneous } \\
\text { groups }\end{array}$ & Cultivar & 2011 & $\begin{array}{c}\text { Homogeneous } \\
\text { groups }\end{array}$ \\
\hline Leo & 0.062 & $\mathrm{x}$ & Kasztelan & 0.06144444 & $\mathrm{x}$ \\
\hline Kasztelan & 0.06428571 & $\mathrm{x}$ & Amulet & 0.06544444 & $\mathrm{x}$ \\
\hline Albus & 0.06742857 & $\mathrm{x}$ & Albus & 0.06644444 & $\mathrm{x}$ \\
\hline Amulet & 0.06828571 & $\mathrm{x}$ & Olga & 0.067 & $\mathrm{x}$ \\
\hline Olga & 0.06942857 & $\mathrm{x}$ & Leo & 0.06766667 & $\mathrm{x}$ \\
\hline Bobas & 0.6161429 & $\mathrm{x}$ & Bobas & 0.5703333 & $\mathrm{x}$ \\
\hline Sonet & 0.6438571 & $\mathrm{X}$ & Optimal & 0.6743333 & $\mathrm{x}$ \\
\hline Granit & 0.7068571 & $\mathrm{X}$ & Granit & 0.6756667 & $\mathrm{X}$ \\
\hline Optimal & 0.744 & $\mathrm{x}$ & & & \\
\hline
\end{tabular}

Table 2. The content of tannins in the seeds of faba bean depending on the location of cultivation in the 2010-

Table 3. The correlation coefficients among the content of nutritional substances, tannins and some agronomic factors in faba bean

\begin{tabular}{|c|c|c|c|c|c|c|}
\hline Characteristic & protein & crude fibre & crude fat & crude ash & tannins & sugars \\
\hline crude fibre & $0.9607 *$ & & & & & \\
\hline crude fat & -0.2775 & -0.0628 & & & & \\
\hline crude ash & 0.9787 & 0.9516 & -0.2842 & & & \\
\hline tannins & -0.9816 & -0.9552 & 0.2697 & -0.9758 & & \\
\hline sugars & -0.9844 & -0.9760 & 0.3933 & -0.9707 & 0.9809 & \\
\hline soil pH & -0.0476 & -0.0374 & -0.0938 & 0.0072 & 0.0250 & 0.2383 \\
\hline precipitations for growing season & 0.1633 & 0.1548 & -0.1469 & 0.1690 & -0.1250 & -0.1436 \\
\hline
\end{tabular}

*- numbers in bold indicate significant differences (for $\alpha=0,05$ )

Table 4. The content of tannins in the seeds of fodder pea depending on the location of cultivation (\% d.m.)

\begin{tabular}{|c|c|c|c|c|c|}
\hline Cultivar & Content & $\begin{array}{c}\text { Homogeneous } \\
\text { groups } \\
\end{array}$ & $\begin{array}{l}\text { Location (place and } \\
\text { direction of Poland) }\end{array}$ & Content & $\begin{array}{c}\text { Homogeneous } \\
\text { groups } \\
\end{array}$ \\
\hline Muza & 0.06716882 & $\mathrm{X}$ & Pawłowice; $S$ & 0.3119797 & $\mathrm{X}$ \\
\hline Marych & 0.07041882 & $\mathrm{X}$ & Kościelec; Central & 0.3537525 & $\mathrm{XX}$ \\
\hline Milwa & 0.2023688 & $\mathrm{X}$ & Świebodzin; $W$ & 0.3558404 & $\mathrm{XX}$ \\
\hline Gwarek & 0.3782688 & $\mathrm{X}$ & Tomaszów Bol.; $W$ & 0.3622988 & $\mathrm{XX}$ \\
\hline Klif & 0.4157188 & $\mathrm{XX}$ & Głodowo; Central & 0.3748434 & $\mathrm{XX}$ \\
\hline Hubal & 0.4158688 & $\mathrm{XX}$ & Białogard; $N W$ & 0.3812525 & $\mathrm{XX}$ \\
\hline Sokolik & 0.4332188 & $\mathrm{XX}$ & Wyczechy; $N$ & 0.3815071 & $\mathrm{XX}$ \\
\hline Model & 0.4441922 & $\mathrm{XX}$ & Bobrowniki; $W$ & 0.3853821 & $\mathrm{XX}$ \\
\hline Eureka & 0.4641688 & $\mathrm{x}$ & Ruska Wieś; $S E$ & 0.3920042 & $\mathrm{XX}$ \\
\hline Pomorska & 0.4706688 & $\mathrm{x}$ & Cicibór Duży; $E$ & 0.4219654 & $\mathrm{XX}$ \\
\hline Turnia & 0.4847637 & $\mathrm{XX}$ & Marianowo; $E$ & 0.482158 & $\mathrm{X}$ \\
\hline Roch & 0.5440188 & $\mathrm{XX}$ & & & \\
\hline Wiato & 0.5763188 & $\mathrm{X}$ & & & \\
\hline
\end{tabular}


Evaluation of the Variation of the Contents of Anti-Nutrients and Nutrients in the Seeds of Legumes

Table 5. The correlation coefficients among the content nutritional substances, tannins and some agronomic factors in seeds of fodder pea cultivars

\begin{tabular}{lccccc}
\hline Characteristic & protein & crude fibre & taninns & sugars & starch \\
\hline crude fibre & $\mathbf{- 0 . 1 5 0 5}$ & & & & \\
taninns & $\mathbf{- 0 . 1 6 2 0}$ & 0.0000 & & & \\
sugars & $\mathbf{0 . 2 7 2 8}$ & $\mathbf{- 0 . 1 9 0 2}$ & $\mathbf{0 . 1 3 2 9}$ & & \\
starch & $\mathbf{- 0 . 4 5 7 1}$ & 0.2730 & -0.0625 & -0.1907 & \\
soil complex & $\mathbf{0 . 1 7 4 6}$ & $\mathbf{0 . 2 2 6 6}$ & -0.0598 & -0.1148 & 0.2141 \\
soil pH & $\mathbf{- 0 . 2 4 6 4}$ & 0.0159 & $\mathbf{0 . 2 2 6 5}$ & $\mathbf{- 0 . 1 2 8 3}$ & $\mathbf{- 0 . 5 9 4 5}$ \\
forecrop & $\mathbf{0 . 2 0 1 0}$ & -0.0858 & -0.0342 & $\mathbf{0 . 2 8 0 7}$ & -0.2141 \\
precipitation for & & & & & \\
growing season & -0.0408 & -0.0732 & 0.1083 & -0.0150 & $\mathbf{- 0 . 4 5 6 6}$ \\
\hline
\end{tabular}

*- numbers in bold indicate significant differences (for $\alpha=0,05$ )

Table 6. The content of total alkaloids in seeds of yellow lupine cultivars depending on cultivar and location of cultivation (\% d.m.)

\begin{tabular}{|c|c|c|c|c|c|}
\hline Cultivar & Content & $\begin{array}{l}\text { Homogeneous } \\
\text { groups }\end{array}$ & $\begin{array}{l}\text { Location (place and } \\
\text { direction of Poland) }\end{array}$ & Content & $\begin{array}{l}\text { Homogeneous } \\
\text { groups }\end{array}$ \\
\hline Baryt & 0.01296481 & $\mathrm{X}$ & Marianowo; $E$ & 0.01194179 & $\mathrm{X}$ \\
\hline Parys & 0.01335641 & $\mathrm{X}$ & Bobrowniki; $W$ & 0.01322236 & $\mathrm{X}$ \\
\hline Talar & 0.01713766 & $\mathrm{X}$ & Głodowo; Central & 0.01382236 & $\mathrm{X}$ \\
\hline Perkoz & 0.01902516 & $\mathrm{X}$ & Uhnin; $E$ & 0.01510902 & $\mathrm{X}$ \\
\hline Taper & 0.01929391 & $\mathrm{x}$ & Świebodzin; $W$ & 0.01579893 & $\mathrm{x}$ \\
\hline Dukat & 0.02106266 & $\mathrm{X}$ & Ruska Wieś; $N E$ & 0.01593569 & $\mathrm{X}$ \\
\hline Lord & 0.02578766 & $\mathrm{X}$ & $\begin{array}{l}\text { Nowy Lubliniec; SE } \\
\text { SESSSSSSSESESE }\end{array}$ & 0.01998464 & $\mathrm{X}$ \\
\hline \multirow[t]{4}{*}{ Mister } & 0.02915016 & $\mathrm{X}$ & Cicibór Duży; $E$ & 0.0247275 & $\mathrm{X}$ \\
\hline & & & Nowa Wieś Ujska; $W$ & 0.02485607 & $\mathrm{X}$ \\
\hline & & & Tomaszów Bol.; W & 0.03008464 & $\mathrm{X}$ \\
\hline & & & Sulejów; Central & 0.03146236 & $\mathrm{x}$ \\
\hline
\end{tabular}

Table 7. The content of gramine in the seeds of yellow lupine cultivars depending on cultivar and location of cultivation (\% d. m.)

\begin{tabular}{|c|c|c|c|c|c|}
\hline Cultivar & Content & $\begin{array}{c}\text { Homogeneous } \\
\text { groups }\end{array}$ & $\begin{array}{l}\text { Location (place and } \\
\text { direction of Poland) }\end{array}$ & Content & $\begin{array}{c}\text { Homogeneous } \\
\text { groups }\end{array}$ \\
\hline Lord & -0.0003843506 & $\mathrm{X}$ & Uhnin; $E$ & -0.0002545094 & $\mathrm{X}$ \\
\hline Mister & -0.0003843506 & $\mathrm{x}$ & Sulejów; Central & -0.0001656205 & $\mathrm{x}$ \\
\hline Talar & -0.0003843506 & $\mathrm{X}$ & Bobrowniki; $W$ & -0.0001545094 & $\mathrm{X}$ \\
\hline Perkoz & -0.0003843506 & $\mathrm{X}$ & Nowy Lubliniec; $S E$ & -0.00009863636 & $\mathrm{X}$ \\
\hline Dukat & -0.0003843506 & $\mathrm{X}$ & Świebodzin; $W$ & -0.00008435065 & $\mathrm{X}$ \\
\hline Taper & 0.0006307062 & $\mathrm{x}$ & Głodowo; Central & -0.00003228716 & $\mathrm{x}$ \\
\hline \multirow[t]{5}{*}{ Parys } & 0.003036956 & $\mathrm{x}$ & Ruska Wieś; $N E$ & 0.00005660173 & $\mathrm{X}$ \\
\hline & & & Marianowo; $E$ & 0.0001870779 & $\mathrm{X}$ \\
\hline & & & Cicibór Duży; $E$ & 0.0008727922 & $\mathrm{X}$ \\
\hline & & & Nowa Wieś Ujska; $W$ & 0.0009156494 & $\mathrm{x}$ \\
\hline & & & Tomaszow Bol.; $W$ & 0.001501364 & $\mathrm{X}$ \\
\hline
\end{tabular}

Table 8. The correlation coefficients among the content of anti-nutritional substances (alkaloids and gramine), nutritional substances and some agronomic factors in yellow lupine seeds

\begin{tabular}{|c|c|c|c|c|c|c|c|}
\hline Characteristic & protein & crude fibre & crude fat & alkaloids & gramine & sugars & starch \\
\hline crude fibre & -0.3102 & & & & & & \\
\hline crude fat & -0.2341 & 0.1771 & & & & & \\
\hline alkaloids & 0.0794 & 0.0390 & 0.0276 & & & & \\
\hline gramine & 0.1012 & -0.0151 & 0.1470 & -0.0857 & & & \\
\hline sugars & -0.0632 & 0.0329 & -0.1096 & 0.0821 & -0.0002 & & \\
\hline starch & -0.0216 & 0.1851 & 0.2196 & 0.4489 & -0.8310 & 0.1732 & \\
\hline soil complex & 0.1734 & -0.0365 & 0.1214 & 0.1982 & 0.0773 & 0.0643 & -0.0116 \\
\hline soil pH & -0.0048 & -0.1115 & -0.0660 & 0.0621 & 0.0352 & -0.1299 & -0.0327 \\
\hline forecrop & 0.0118 & 0.2253 & -0.2162 & 0.0335 & -0.0395 & 0.1806 & 0.0533 \\
\hline
\end{tabular}


Evaluation of the Variation of the Contents of Anti-Nutrients and Nutrients in the Seeds of Legumes

$\begin{array}{lllllllll}\text { precipitation for } & 0.0645 & 0.0089 & \mathbf{- 0 . 2 2 5 0} & 0.0438 & -0.0339 & -0.0022 & 0.0409\end{array}$

growing season

*- numbers in bold indicate significant differences (for $\alpha=0,05$ )

Table 9. The content of total alkaloids in the seeds of blue lupine depending on the cultivar and location of cultivation (\% d.m.)

\begin{tabular}{|c|c|c|c|c|c|}
\hline Cultivar & Content & $\begin{array}{l}\text { Homogeneous } \\
\text { groups }\end{array}$ & $\begin{array}{l}\text { Location (place and } \\
\text { direction of Poland) }\end{array}$ & Content & $\begin{array}{c}\text { Homogeneous } \\
\text { groups }\end{array}$ \\
\hline Dalbor & 0.001373278 & $\mathrm{X}$ & Głodowo; Central & 0.05260664 & $\mathrm{X}$ \\
\hline Heros & 0.005573278 & $\mathrm{X}$ & Wyczechy; $N$ & 0.1526019 & $\mathrm{XX}$ \\
\hline Regent & 0.006265688 & $\mathrm{X}$ & Nowy Lubliniec, $S E$ & 0.1580213 & $x X$ \\
\hline Neptun & 0.01197759 & $\mathrm{X}$ & Wrócikowo; $N$ & 0.1593477 & $\mathrm{XX}$ \\
\hline Graf & 0.01252997 & $\mathrm{X}$ & Rarwino; $N W$ & 0.1638559 & $\mathrm{XX}$ \\
\hline Zeus & 0.01368712 & $\mathrm{X}$ & Marianowo; $S$ & 0.1752227 & $\mathrm{XX}$ \\
\hline Kalif & 0.01399188 & $\mathrm{X}$ & Cicibór Duży; $S$ & 0.1759497 & $\mathrm{xX}$ \\
\hline Baron & 0.0179676 & $\mathrm{X}$ & Bobrowniki; $W$ & 0.1789386 & $X X$ \\
\hline Kadryl & 0.02164426 & $\mathrm{X}$ & Kawęczyn; Central & 0.1870463 & $X X$ \\
\hline Sonet & 0.02206331 & $\mathrm{X}$ & Ruska Wieś; $N S$ & 0.215429 & $\mathrm{x}$ \\
\hline Boruta & 0.03128712 & $\mathrm{X}$ & Kościelec; Central & 0.2293867 & $\mathrm{x}$ \\
\hline Bajor & 0.0469395 & $\mathrm{X}$ & & & \\
\hline Mirela & 1.062815 & $\mathrm{x}$ & & & \\
\hline Karo & 1.084401 & $\mathrm{x}$ & & & \\
\hline
\end{tabular}

Table 10. The correlation coefficients among the content of anti-nutritional substance (alkaloids), nutritional substances and some agronomic factors in blue lupine seeds

\begin{tabular}{|c|c|c|c|c|c|c|}
\hline Characteristic & protein & crude fibre & crude fat & sugars & starch & alkaloids \\
\hline crude fibre & -0.2684 & & & & & \\
\hline crude fat & -0.2468 & 0.0026 & & & & \\
\hline sugars & -0.0086 & 0.1783 & -0.1332 & & & \\
\hline starch & -0.0433 & 0.0280 & 0.0394 & -0.2848 & & \\
\hline alkaloids & 0.0959 & -0.0297 & -0.0774 & -0.2143 & -0.1884 & \\
\hline soil complex & -0.1057 & -0.1607 & 0.1289 & 0.1332 & -0.0551 & -0.0363 \\
\hline soil pH & -0.1621 & -0.1455 & 0.0564 & 0.0162 & 0.1160 & 0.0145 \\
\hline forecrop & 0.1254 & -0.2861 & -0.1650 & 0.0212 & -0.0734 & -0.0002 \\
\hline precipitation for growing season & -0.0243 & 0.0067 & -0.3635 & 0.1781 & 0.0509 & 0.0069 \\
\hline
\end{tabular}

*- numbers in bold indicate significant differences (for $\alpha=0,05$ )

Table 11. The correlation coefficients among the content of nutritional substances and some agronomic factors in seeds of multiuse pea cultivars

\begin{tabular}{|c|c|c|c|c|}
\hline Characteristic & protein & crude fibre & sugars & starch \\
\hline crude fibre & 0.0922 & & & \\
\hline sugars & -0.2003 & -0.1138 & & \\
\hline starch & -0.1804 & 0.1276 & -0.4830 & \\
\hline soil complex & 0.1541 & -0.0194 & -0.1269 & 0.1601 \\
\hline soil pH & -0.2713 & -0.1710 & 0.2993 & 0.0941 \\
\hline forecrop & -0.0835 & -0.0212 & 0.3148 & -0.1695 \\
\hline precipitation for growing season & 0.3875 & 0.1928 & -0.3945 & 0.1588 \\
\hline
\end{tabular}

*- numbers in bold indicate significant differences (for $\alpha=0,05$ ) 